Int. J. Dev. Biol. 52: 43-53 (2008)

doi: $10.1387 / \mathrm{ijdb} .072274 \mathrm{yl}$

\title{
Spa-1 regulates the maintenance and differentiation of human embryonic stem cells
}

\author{
YOUNG-JIN LEE 1,2 , HEE-YOUNG NAH ${ }^{1}$, SEOK-HO HONG ${ }^{1}$, JI-WON LEE ${ }^{1}$, ILKYUNG JEON ${ }^{1}$, JHANG HO PAK ${ }^{3}$, \\ JOO-RYUNG HUH ${ }^{4}$, SUNG-HOON KIM ${ }^{1}$, HEE-DONG CHAE ${ }^{1}$, BYUNG-MOON KANG ${ }^{1}$, CHUL GEUN KIM² \\ and CHUNG-HOON KIM ${ }^{1, *}$
}

\begin{abstract}
${ }^{1}$ Dept. of Obstetrics \& Gynecology, College of Medicine, University of Ulsan, Asan Medical Center, ${ }^{2}$ Dept. of Life Science, College of Natural Sciences and Stem Cell Research Center, Hanyang University, ${ }^{3}$ Dept. of Obstetrics \& Gynecology, College of Medicine, Asan Institute for Life Science, Asan Medical Center and ${ }^{4}$ Dept. of Pathology, College of Medicine, University of Ulsan, Asan Medical Center, Seoul, Republic of Korea
\end{abstract}

\begin{abstract}
Human embryonic stem cells (hESCs) are pluripotent, whereby they can proliferate endlessly and differentiate into many different cell types. At the molecular level, little is known of the mechanisms underlying their capability for self-renewal and differentiation. In the present study, we established two new hESC lines (AMC-hES1 and AMC-hES2) and demonstrated the existence of a regulator that may be a key molecule in hESC dynamics. Spa-1 is a principal Rasproximate 1 (Rap1) GTPase-activating protein in hematopoietic progenitor cells that regulates Rap1-related signal transduction and is expressed restrictively in human adult tissues (bone marrow, thymus, and spleen). To investigate its functions in hESCs, we examined spa-1 expression profiles during hESC differentiation and used RNA interference (RNAi) to downregulate spa1 in these cells. Our results show that Spa-1 is expressed in undifferentiated hESCs and is downregulated during hESC differentiation. In addition, the process of passing from the mode of self-renewal to that of differentiation in hESCs was regulated by spa-1 via Rap1/Raf/mitogenactivated protein kinase kinase/extracellular signal-related kinase signaling. An RNAi expression vector against spa-1 (pSUPER.retro.puro) was transfected into hESCs, which were seen to differentiate into three germ layers in spite of being in the undifferentiated condition. Based on our findings, therefore, it appears that spa-1 may be involved in hESC dynamics, and our results provide fundamental information regarding the self-renewal and differentiation of hESCs.
\end{abstract}

KEY WORDS: signal transduction, fate decision, gene regulation, differentiation

\section{Introduction}

Human embryonic stem cells (hESCs), which are being considered as a new therapeutic material for the treatment of degenerative disorders, have specific properties that allow them to differentiate into several cell lineages, and can divide indefinitely when in the undifferentiated condition. hESC lines were first established in 1998 (Thomson et al., 1998), and these pluripotent cells have been isolated from germ cells and blastocysts (Papaioannou et al., 1984; Rossant and Papaioannou, 1984; Shamblott et al., 1998; Thomson and Odorico, 2000).

It was thought that the self-renewal and differentiation activities of mouse embryonic stem cells (mESCs) and hESCs are regulated by the coordinated interaction between several intrinsic and extrinsic factors. Janus kinase-signal transducer and activator of transduction (Jak-STAT) signaling, which is activated by leukemia inhibitory factor (LIF), is crucial for the maintenance of the self-renewal activity of mESCs (Yoshida et al., 1994; Niwa et al., 1998; Burdon et al., 1999; Matsuda et al., 1999; Niwa, 2001).

\footnotetext{
Abbreviations used in this paper: bFGF, basic fibroblast growth factor; CM, conditioned medium; EB, embroyid body; hESC, human embryonic stem cell; ICM, inner cell mass; Jak, janus kinase; LIF, leukemia inhibitory factor; Rap, ras-proximate; siRNA, small interference RNA; spa, signal-induced proliferation-associated gene; STAT, signal transducer and activator of transduction.
}

*Address correspondence to: Chung-Hoon Kim. Dept. of Obstetrics and Gynecology, College of Medicine, University of Ulsan, Asan Medical Center, 388-1 Pungnap-2dong, Songpa-gu, Seoul 138-736, Korea. Fax: +82-2-3010-5059. e-mail: yjleelee@amc.seoul.kr 
In addition, a combination of the LIF and bone morphogenic protein signaling pathways (Ying etal., 2003), as well as transcription factor Nanog (Mitsui et al., 2003) are required for the selfrenewal of mESCs, but it is unclear that whether LIF acts alone or with other (unknown) factors. By comparison, the self-renewal activity of hESCs is independent of LIF signaling (Thomson et al., 1998; Reubinoff et al., 2000; Schuringa et al., 2002), and they can be cultured on feeder cells, which are mitotically inactivated, with hESC culture medium and basic fibroblast growth factor (bFGF and FGF2), which is essential for the maintenance of hESCs (Amit et al., 2004). It has been reported that hESCs can be cultured and maintained with LIF and/or transforming growth factor $\beta$-1 (TGF $\beta$-1), but these results were not seen as a significant advancement in the culturing of hESCs (Amit et al., 2004). Recently, it has been demonstrated that wnt pathway genes may also be regulators involved in hESC dynamics (Walsh et al., 2003; Sato et al., 2004; James et. al., 2005; Prowse et. al., 2005). Boyer et. al. (2005) identified OCT4, SOX2, and NANOG target genes using genome-scale location analysis, and oct4-dependent transcriptional networks (Babaie et al., 2007) as well as fibroblast growth factor 2 (FGF2) signaling mechanism involved in transforming growth factor $\beta$ (Greber et al., 2007) were reported. Despite these reports, there are much uncovered knowledge about the molecular mechanisms that regulate the maintenance and differentiation of hESCs. Thus, we scanned genes that are expressed uniquely in undifferentiated hESCs by oligo DNA chip, which resulted in the identification of signal-induced proliferationassociated gene-1 (spa-1) as an overexpressed gene in undifferentiated hESCs compared to differentiated hESCs (day-20 embryoid bodies; Supplementary Table 1).

Spa-1 is a principal Rap1 (Ras-proximate 1) GTPase-activating protein in hematopoietic progenitor cells, and regulates Rap1related signal transduction (Kurachi et al., 1997; Gao et al., 1999; Pak et al., 2001; Roy et al., 2002). The Spa-1 family consists of several distinct proteins, including spa-1, E6-targeted protein 1 (E6TP1), spine-associated RapGAP (SPAR), and spa-1-like proteins (SPA-Ls), all of which show a specific cellular distribution in tissues (Kurachi et al., 1997; Gao et al., 1999; Pak et al., 2001). In Spa-1-deficient mice, there appears to be an increase in the expression of Rap1GTP in progenitor cells in the bone marrow, and this is associated with an increase in the number of blood leukocytes following constitutive activation of extracellular signalrelated kinase (ERK). The increased population of leukocytes was comprised predominantly of mature granulocytes, closely resembling the condition of human chronic myelogenous leukemia (CML) in the chronic phase (Ishida et al., 2003). It has been suggested that this phenomenon is mediated, at least in part, by Rap1-B-raf-mediated activation of ERK (Kometani et al., 2004). In humans, the spa-1 gene is located on chromosome 11q13.3, which is one of the hot spots in human hematologic malignancies (Wada et al., 1997; Wong, 1999).

We have investigated the expression of spa-1 and spa-1 effectors to define the possible influence of spa-1-involved signaling on the maintenance and differentiation of hESCs. In addition, we examined the spa-1 signaling pathway to determine the molecular mechanisms that control the self-renewal activity of hESCs. The results of this study suggest that spa-1 can influence the maintenance and differentiation of hESCs via the Rap1/Raf/
AMC-hES1


Fig. 1. Derivation and characterization of human embryonic stem cell (hESC) lines. (A,H) Colonies of established and undifferentiated hESCs. Expression analyses of hESC marker proteins for the two novel hESC lines established (AMC-hES1 and AMC-hES2): alkaline phosphatase

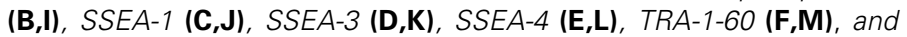

TRA-1-81 (G,N). Scale bars, $100 \mu \mathrm{m}$.
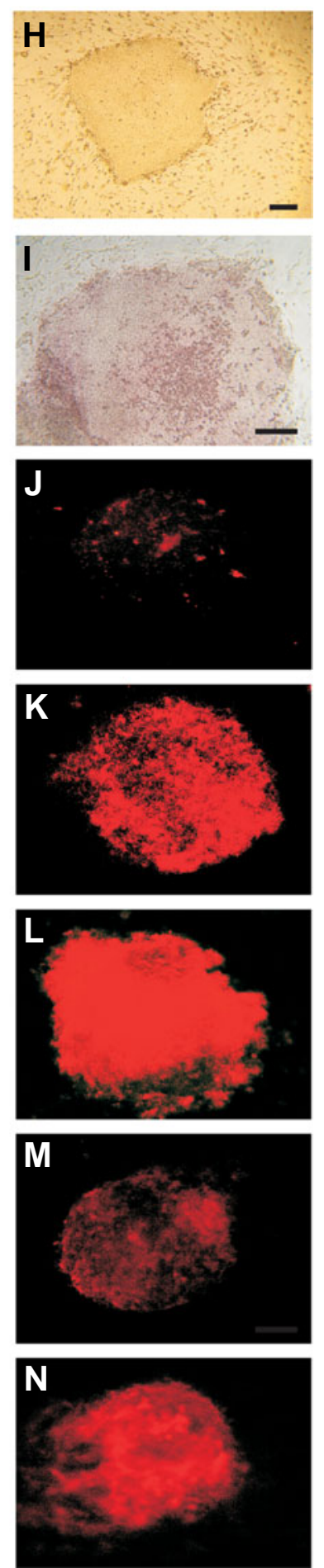
mitogen-activated protein kinase kinase (MEK)/ERK pathway.

\section{Results}

Derivation and cultivation of two new human embryonic stem cell (hESC) lines (AMC-hES1 and AMC-hES2)

Two novel hESC lines (AMC-hES1 and AMChES2) were derived from in-vitro-cultured human blastocysts by isolation of the ICM. ICMs were immunosurgically isolated from five blastocysts and cultured onto MEF feeder layers (Solter and Knowles, 1975). After 5-7 days of cultivation, clumps of tightly associated cells were observed, and these clumps were mechanically dissociated and replated onto MEF feeder layers. Two cell lines, AMC-hES1 and AMC-hES2, were grown for 40 passages in vitro, at which time they still consisted mainly of cells with the morphology of undifferentiated hESCs (Fig. 1A and 1H). Established hESCs exhibited a large, compact, multicellular morphology with a distinguishable border toward the MEF feeder layers, and had a high nucleus:cytoplasm ratio and prominent nucleoli at high magnification. During the maintenance of hESCs, regions where cells exhibited differentiated morphology were mechanically removed before passaging. The growth rate of each of these two cell lines (24-48 h) was comparable to that of other hESC lines (Miz-hES4 and MizhES5) and these lines were successfully frozen and thawed.

\section{Characterization of hESC lines}

The undifferentiated state of the embryonic stem cell is characterized by a high level of expression of AP and the stem cell transcription factor octamer-binding transcription factor 3/4 (oct-3/ 4). hESCs typically express SSEA-3 and SSEA-4 but not SSEA-1, and express the keratin-sulfate-associated antigens TRA-1-60 and TRA-1-81 (Andrews, 1984; Andrews et al., 1984; Fenderson et al., 1987; Pease etal., 1990; Thomson et al., 1998; Reubinoff et al., 2000). An evaluation of hESC lines for surface markers that characterize undifferentiated hESCs showed that two hESC lines were positive for AP (Fig. 1B and 1I), SSEA-3 (Fig. 1D and 1K), and

TABLE 1

OVERVIEW OF CHARACTERIZATION FOR THE TWO NEW HUMAN EMBRYONIC STEM CELL (hESC) LINES (AMC-HES1 AND AMCHES2)

\begin{tabular}{lcc} 
Marker & AMC-hES1* & AMC-hES2 $^{*}$ \\
\hline SSEA-1 & " & " \\
SSEA-3 & + & + \\
SSEA-4 & + & + \\
TRA-1-60 & + & + \\
TRA-1-81 & + & + \\
Karyotyping & $46, \mathrm{XY}$ & $46, \mathrm{XY}$ \\
Oct-3/4 & + & + \\
Teratomas & + & + \\
Freeze/thaw & + & + \\
\hline
\end{tabular}

${ }^{*}$ Characterization of hESC lines on a mouse embryonic fibroblast in main text feeder layer.
B
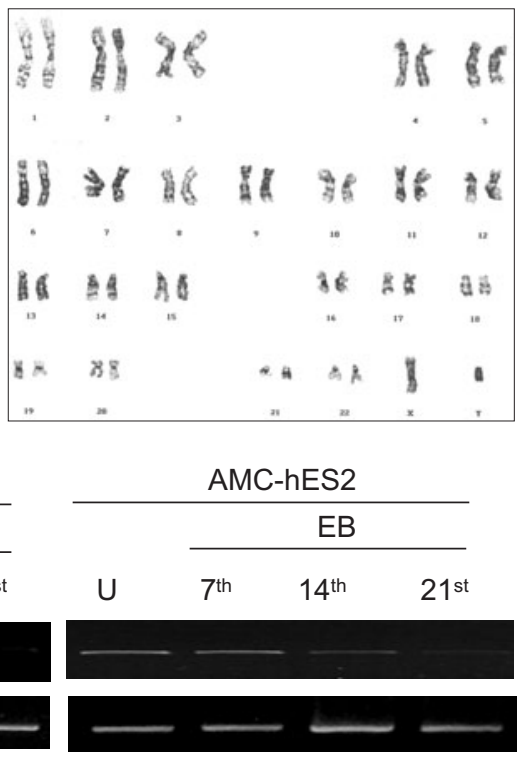

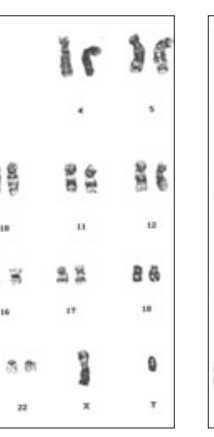

AMC-hES1
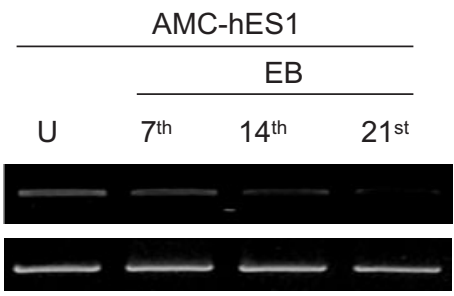

Fig. 2. Characterization of hESC lines. Karyotypes of AMC-hES1 and AMC-hES2 after 32 passages; (A) AMC-hES1, $46 X Y$ and (B) AMC-hES2, $46 X Y$. (C) Expression patterns of octamer-binding transcription factor (oct-3/4) mRNAs (self-renewal marker) during hESC differentiation ( $U$, undifferentiated; EB, embryoid bodies at day-7, -14, and -21).

SSEA-4 (Fig. 1E and 1L), but negative for SSEA-1 (Fig. 1C and 1J). The two cell lines were also found to be positive for TRA-1-60 (Fig. $1 \mathrm{~F}$ and $1 \mathrm{M}$ ) and TRA-1-81 (Fig. $1 \mathrm{G}$ and $1 \mathrm{~N}$ ).

Karyotypic analysis was performed at 32 passages, and both hESC lines were found to have an apparently normal $X Y$ human karyotype (Fig. 2A and $2 \mathrm{~B}$ ).

The POU transcription factor oct-3/4 is a stem-cell marker that is expressed in undifferentiated hESCs and downregulated upon differentiation (Rao et al., 2004). Using RT-PCR we showed that both AMC-hES1 and AMC-hES 2 expressed oct-3/4, and that its expression decreased upon differentiation (Fig. 2C).

To test for pluripotency in vivo, AMC-hES1 and AMC-hES2 were injected into the testicular capsule of SCID mice. Twelve weeks later, on autopsy, the resulting lesions were multicystic tumors with solid areas (Fig. 3A) that had replaced the testicular tissue, although a rim of residual seminiferous tubules was observed in smaller tumors (Fig. 3B). No metastatic spread was identified outside the testicles. Histologically, the tumors were composed of a mixture of tissues derived from all three germ layers, including cartilage, muscle, bone, glandular epithelium, squamous epithelium, and primitive neuroectoderm (Fig. 3C-H). The characteristics of the two newly established hESC lines (AMChES1 and AMC-hES2) are summarized in Table 1.

\section{Large-scale analysis of gene expression in undifferentiated and differentiated $h E S C s$}

The mean values of the intensities of each spot in the three experiments were calculated, and shown in Fig. 4A. Of 19104 known genes examined (Supplementary table 1), changes in mRNA expression were detected in 1731 genes: 564 (Supplementary table 2) or 1173 (Supplementary table 3) were activated in undifferentiated hESCs or differentiated hESCs, respectively, and 
Only $9 \%$ of all examined genes were activated or repressed more than two folds (Fig. 4B). These genes were classified into ten functional categories based on biological functions: apoptosis-, cell cycle-, cell death- cellular-physiological process-, immune response-, response to stress-, signal transduction-, transcription, chromatin structure-related and not determined (ND) genes.

\section{Expression profiles of Spa-1 during hESC differentiation and in adult tissues}

Expression analyses of human spa-1 were performed in undifferentiated or differentiated hESCs and in human adult tissues using RT-PCR. First of all, we examined the differentiation potential of the AMC-hES1 line by examining the expressions patterns of germ-layer marker genes such as alpha-1 antitrypsin $(\alpha 1 A T)$, albumin, carnitine-acylcarnitine translocase $(C A C T)$, brachyury
A
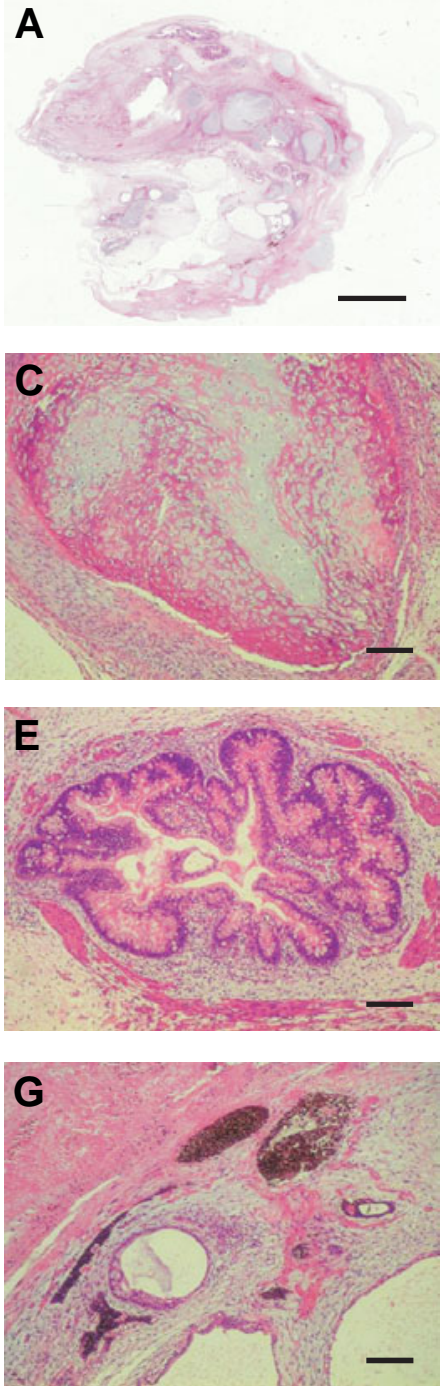

B
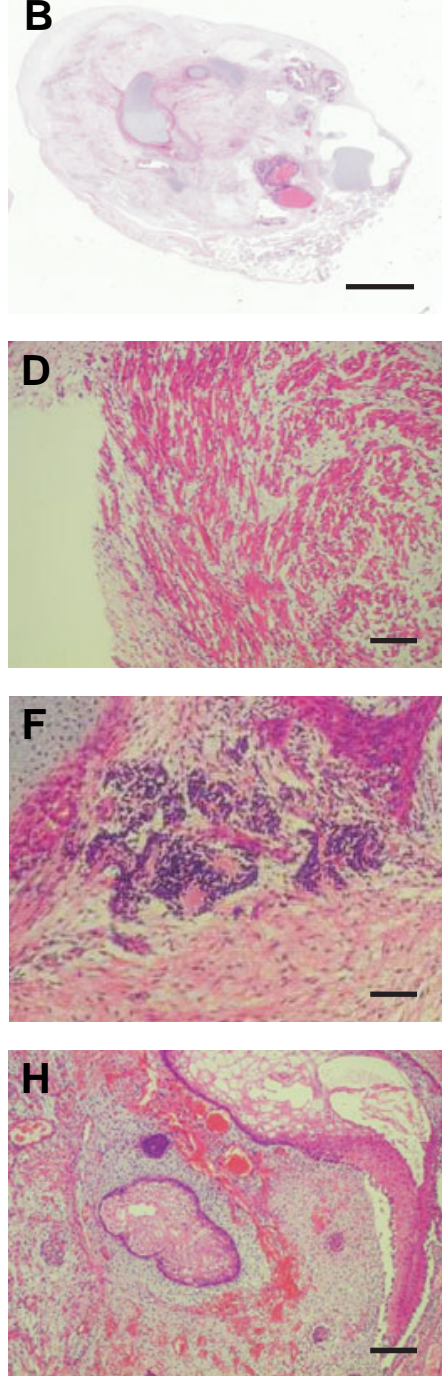

(brachyury), and the 68-kD neurofilament subunit (NF-68kD). Spa1 transcripts were decreased following AMC-hES1 differentiation, as were the pluripotency marker genes, oct-3/4, nanog and sox2 (Fig. 5A). The expression profile of spa-1 was confirmed in three other hESC lines (AMC-hES2, Miz-hES4, and Miz-hES5; Fig. 5B). In human adult tissues, spa-1 was expressed more strongly in the cervix, heart, kidney, lung, ovary, placenta, spleen, testis, and thymus compared to adipose tissue, bladder, colon, esophagus, prostate tissue, skeletal muscle, and small intestine (Fig. 5C).

\section{Spa-1-related Rap1 Signaling could be involved in hESC Maintenance and Differentiation}

Spa-1 is a Rap1 GTPase-activating protein that is present in several cells and tissues, and is involved in the regulation of Rap1regulated signal transduction (Harritori et al., 1995; Kurachi et al.,
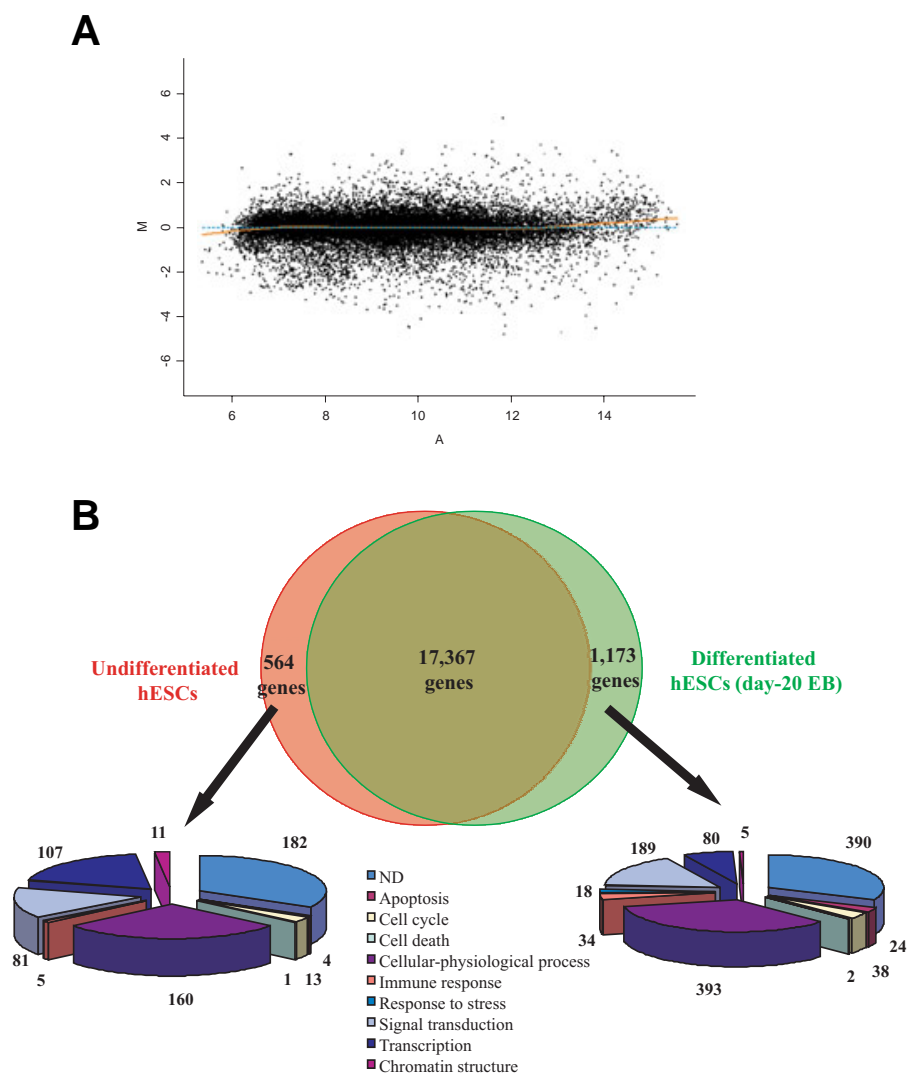

Fig. 3 (Left). In vivo differentiation of AMC-hES1 and AMC-hES2. Whole-mount section of a testicular lesion from an SCID mouse inoculated with AMC-hES1 (A) or AMC-hES2 (B). The tumors are solid and cystic, and have largely replaced the testicular tissue; scale bars, $2 \mathrm{~mm}$ for $(A, B)$. Histologic appearance of the elements in the teratomas formed by AMC-hES1 and AMC-hES2: (C) cartilage and bone, (D) smooth muscle bundles, (E) gut-like tubular structures with goblet cells, containing glandular epithelium and smooth muscle layers, (F) primitive neural epithelium, (G) retina-like structure with melanin-pigmented choroid epithelium, and $\mathbf{( H )}$ squamous epithelium; scale bars, $100 \mu \mathrm{m}$.

Fig. 4 (Right). Expression profiles of genes in hESCs and differentiated hESCs (20-day EB). (A) MA plot (M, exression ratio; $A$, signal intensity) represents genes activated and repressed in undifferentiated hESCs and differentiated hESCs (20-day EB). The MA plot is used to represent the (R, G) data ( $R$, red for Cy5; $G$, green for $C y 3$ ) where $M=\log _{2} R / G$ and $A=\log _{2}(R x G)$. (B) Venn diagram of genes preferentially expressed in undifferentiated hESCs or differentiated hESCs. ND, not determined. 
1997). To evaluate whether spa- 1 is capable of regulation in hESCs, we examined spa-1-associated signal regulation in undifferentiated and differentiated AMChES1 cells. Rap1 (Rousseau-Merck et al., 1990), Raf1 (Cook et al., 1993; Schmitt and Stork, 2001) and Braf (Vossler et al., 1997) were expressed in both undifferentiated and differentiated hESCs, and exhibited no statistically certified change in their expressions (Fig. 6A). To quantify Rap1 activity, we used RalGDSRBD protein, which binds preferentially to GTP-Rap1 (Mochizuki et al., 1999). Rap1 was significantly activated by differentiation in the AMC-hES1 line compared to undifferentiated cells (Fig. 6B). Since Raf-1 and B-raf were activated when these proteins were phosphorylated at Ser ${ }^{338}$ (Roy et al., 1998; Chiloeches etal., 2001) and Thr ${ }^{598} /$ Ser $^{601}$ (Zhang and Guan, 2000), respectively, we examined whether Rap1 stimulates the phosphorylation of endogenous Raf- 1 or B-raf at the corresponding residues in undifferentiated and differentiated AMC-hES1 cells. As shown in Fig. 6C, the phosphorylation of B-Raf ( $\left.\mathrm{Thr}^{598} / \mathrm{Ser}^{601}\right)$ was stimulated by differentiation of AMC-hES1, but that of Raf-1 $\left(\mathrm{Ser}^{338}\right)$ was decreased. Also, activation level of ERK1/ 2 was slightly decreased in differentiated AMC-hES1 (Fig. 6D). These data indicate that spa-1 is expressed in hESC lines and that phosphorylation-induced activation of Raf-1 or B-raf is dependent on Rap1 status, which is regulated by spa-1.

To study the role of spa- 1 in the regulation of hESCs in vitvo, we used the pSUPER system to stably suppress the expression of the spa-1 gene. The pSUPER construct consists of an H1-RNA promoter clone next to the 19-nucleotide spa-1sequence, separated by a short, 9-nucleotide spacer that forms the hairpin, followed by the reverse complement of the same nucleotide sequence (Fig. 7A). AMC-hES1 cells were transfected with pSUPER-spa-1 (used S1 target sequence) with or pSUPER-con (used C1 target sequence), and were selected with puromycin for 7 days. As shown in Fig. 7B, we observed that the cellular levels of spa-1 were diminished but not totally eliminated. In the pSUPER-spa-1 hESCs, Rap1 was significantly activated in the pSUPER-spa-1 cells compared to the wild-type cells and the pSUPER-Con, and the activity of Raf-1 or B-raf was decreased or increased in the pSUPER-spa-1 cells, respectively. In addition, self-renewal activity was decreased in pSUPER-spa-1-transfected hESCs compared to that of wild type and pSUPER-contransfected cells (Fig. 7C). Endoderm and mesoderm marker genes were highly expressed but expression of ectoderm marker gene was decreased in spa-1-diminished hESCs compared to that of wild type and control hESCs (Fig. 7C). The similar results were observed in the other experiment used S2 and C2 target sequence for silencing of spa-1 expression (data not shown).

\section{Discussion}

Human embryonic and adult stem cells have been considered as candidate materials of cell therapy for degenerative diseases. To be applied to cell therapy, the mechanisms underlying the self-

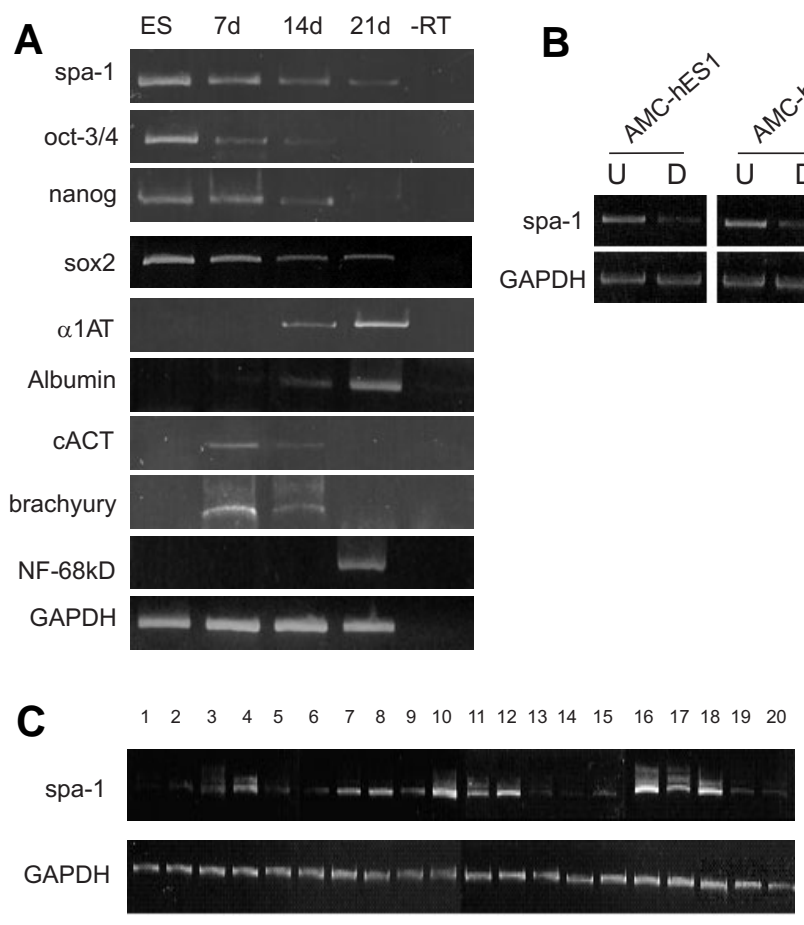

Fig. 5. Expression profile of spa-1 in AMC-hES lines and human adult tissues. (A) Expression profiles of spa-1 and germ-layer marker genes [oct-3/4, nanog and sox-2 for pluripotency; alpha-1 antitrypsin ( $\alpha 1 \mathrm{AT}$ ) and albumin for endoderm; carnitine-acylcarnitine ( for ectoderm] were analyzed in differentiated hESCs (day-7, -14, and -21 EB ; -hEST line) using semiquantitative reverse-transcriptase polymerase chain reacingly, the spa-1 expression pattern was similar to that of the pluripotent marker genes (oct-3/4, nanog and sox-2). GAPDH was used as a loading control. Semiquantitative RT$P C R$ analysis of spa-1 expression in (B) four hESC lines ( $U$, undifferentiated; $D$, lane 14, skeletal muscle; lane 15, small intestine; lane 16, spleen; lane 17, testis; lane 18, thymus; lane 19, thyroid; lane 20, trachea).

renewal and differentiation of these stem cells, as well as their involvement in other cellular events, must be clearly defined. In the study described here, we established two novel hESC lines (AMC-hES1 and AMC-hES2) and analyzed their capability for self-renewal and multilineage differentiation. Examination of the two newly established hESC lines revealed that both exhibited common features of hESCs, such as expression of certain cell surface epitopes (SSEA-3, SSEA-4, TRA-1-60, and TRA-1-81), high AP activity, cell morphology (Fig. 1), a normal karyotype (AMC-hES1, 46XY; AMC-hES2, 46XY; Fig 2A and 2B), and the ability to differentiate into three germ layers (Fig. 3). In addition, these two new cell lines expressed oct-3/4, a transcription factor that is expressed only in pluripotent cells and, as also seen in these cell lines, is downregulated during differentiation (Fig. 2C). Our established hESC lines have properties that have also been described by other research groups (Thomson et al., 1998; Park et al., 2003), and could provide us with fundamental information for hESC research.

If $\mathrm{hESC}$ are to be useful in further applications, it is necessary 
A



C
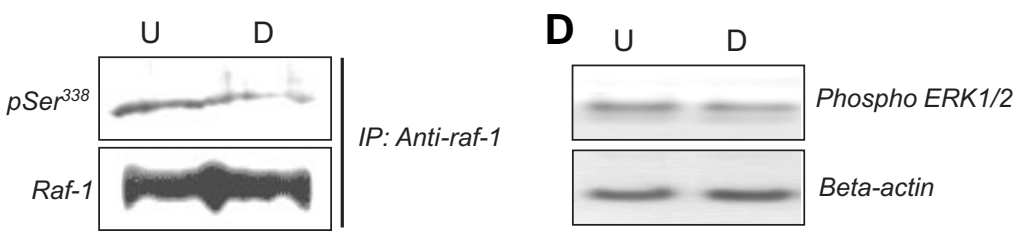

B

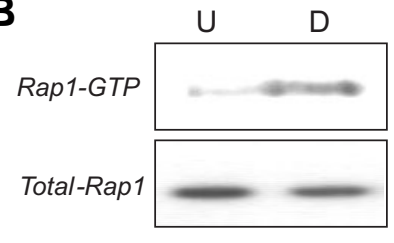

(1)

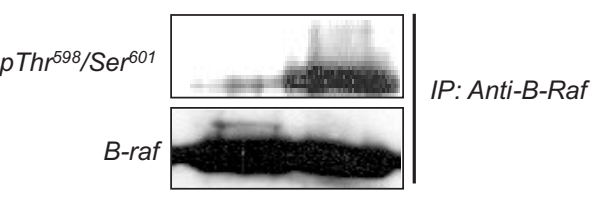

Fig. 6. Switching of Raf-1 and B-raf activation between undifferentiated and differentiated hESCs. (A) Expression profiles of spa-1 downstream signaling molecules by Western blotting. Oct-3/4 was used as a control for differentiation of the AMC-hES1 line and beta-actin was used as a loading control. (B) Rap-1 activation was analyzed in undifferentiated (U) and differentiated (D) AMC-hES1 cells using RalGDS-RBD. (C) Undifferentiated and differentiated AMC-hES1 lysates were immunoprecipitated (IP) with anti-Raf-1 or anti-B-raf antibodies and immunoblotted with antiphosphoserine ${ }^{338}$ antibody or antiphospho-Thr ${ }^{598} / \mathrm{Ser}^{601}$ antibody, respectively. (D) Levels of phosphorylated ERK1/ 2 between $U$ and D cells. $U$, undifferentiated AMC-hES1 line; D, day-21 EB derived from the AMC-hES1 line.

to understand the molecular nature of their capability for selfrenewal and differentiation. In the present study, we identified genes that were preferentially expressed in undifferentiated or differentiated hESCs using cDNA microarray. Microarray results showed that only $9 \%$ (1737 of 19104 ) of all examined genes spotted on the microarray slide were activated or repressed more than twofold in undifferentiated or differentiated hESCs, respectively (Fig. 4). As known, self-renewal marker genes (oct-4, nanog and sox2) were activated in undifferentiated hESC and repressed in differentiated hESCs in our data. Also, 3 germ layer marker genes were activated in differentiated hESCs (Supplementary Table 1), so, our microarray experiment was confirmed based on published data. In our microarray results, spa-1 gene was activated in undifferentiated hESCs compared to differentiated hESCs, and have demonstrated in the present study that spa-1 signaling is needed for the maintenance of hESCs.

Spa-1 is a mitogen-induced GTPase-activating protein and was isolated from a fetal liver-derived immature cell line; its expression is induced when cells are in a proliferating state

(Hattori et al., 1995). Spa-1 encodes a principal Rap1-specific GAP in lymphohematopoietic tissues (Kurachi et al., 1997), and its family regulates Rap1-associated signal transduction (Gao et al., 1999; Pak et al., 2001; Roy et al., 2002). As seen in Fig. 5A and 5B, spa-1 was expressed in four hESC lines (AMC-hES1, AMC-hES2, MizhES4, and Miz-hES5) and was downregulated during hESC differentiation (day-14 EB). These results suggest that spa-1 plays an important role in hESC self-renewal via the Rap1/Raf/ERK signal pathway, and that it is one of the candidate factors in the regulation of hESC dynamics.

Based on the expression of spa-1, we focused on Rap1/Raf/ERK signal pathways in undifferentiated and differentiated hESCs. Expression of Rap1, Raf-1 and B-raf was not changed. In addition, Rap1 and B-raf were activated, whereas Raf-1 was inactivated during differentiation (Fig. $6)$. Several studies have documented that Rap1 attenuates Ras-mediated ERK activation in certain cell models and inactivates Raf- 1 by sequestering it, while Rap1 activates B-raf (Bos et al., 2001; Caron, 2003; Carey et al., 2003; Stork, 2003). Importantly, cell fate is determined by the duration of ERK signaling by Raf-1 and B-raf as a result of differential activation kinetics on their substrate MEK in the PC12 cell model (O'Neill and Kolch, 2004). From these results we suggest that for hESCs, passage from the self-renewal mode to the differentiation mode is dependent on the activity of Raf-1 or B-raf on Rap1 regulation.

As seen in Fig. 7, we isolated spa-1-suppressed hESCs using the siRNA technique; these cells were seen to differentiate into endoderm and mesoderm cell types and rarely expressed the pluripotent marker genes (oct-3/4, nanog and sox-2). In addition, in spa-1 suppressed hESCs, Rap1 was activated and the activity of Raf-1 or Braf was decreased or increased, respectively, in spite of the prevailing undifferentiated culture conditions. Also, the phosphorylated form of ERK1/2 was slightly decreased in spa1 suppressd hESCs (Fig. 7B). Interestingly, spa-1 suppressed hESCs were differentiated into endoderm and mesoderm cell types not ectoderm (Fig. 7C). This result suggested that at least spa-1 involved signaling pathways maintain self-renewal activity and can be a factor of determination for hESCs differentiation, in addition, these pathways (Fig. 8) are needed to differentiate into ectoderm cell types. It was reported that spa-1-deficient mice developed myeloid disorders that resemble chronic-phase human CML and myeloproliferative stem-cell disorders (Ishida etal., 2003). Several reports have also suggested that deregulation of Rap1 signaling is£involved in malignancy in epithelial cell transformation (Gao et al., 2001), leukemia in mice (Dupuy et al., 2001), and in human cancer cell lines (Yajnik et al., 2003). These findings suggest that regulation of Rap1 activation by spa-1 or Rap1-activating proteins is crucial for cell fate decisions and tumorigenesis and, as such, spa-1 could be one of the molecules that regulate hESCs via Rap1/Raf/MEK/ERK signaling. 
It is generally accepted that hESCs are independent of LIF signaling (Humphrey et al., 2004) and that wnt and FGF2/PI3K/ Akt/PKB positively regulate the expression of key molecules involved in hESC self-renewal, although the signaling pathways remain unclear (Mitalipova et al., 2003; Amit et al., 2004; Sato et al., 2004; Dvorak et al., 2005). It was reported that bFGF (FGF2) prevents the apoptosis induced by death-receptor stimulation, via Raf-1 activation in a MEK-independent manner (Alavi et al.,
2003), and that B-raf is a crucial effecter for Ras-mediated tumorigenesis in several tumor types (Mercer and Pritchard, 2003). Also, Amstrong et al. (2006) reported that PI3K/AKT, MARK/ERK and NFkappa $\beta$ signallings are necessary to maintain the pluripotency of hESCs.

These findings and ours suggest that spa- 1 is expressed in hESC lines and regulates Rap1 activity by modulating the activities of Raf-1 or B-raf, thus determining whether cells enter the self-
A
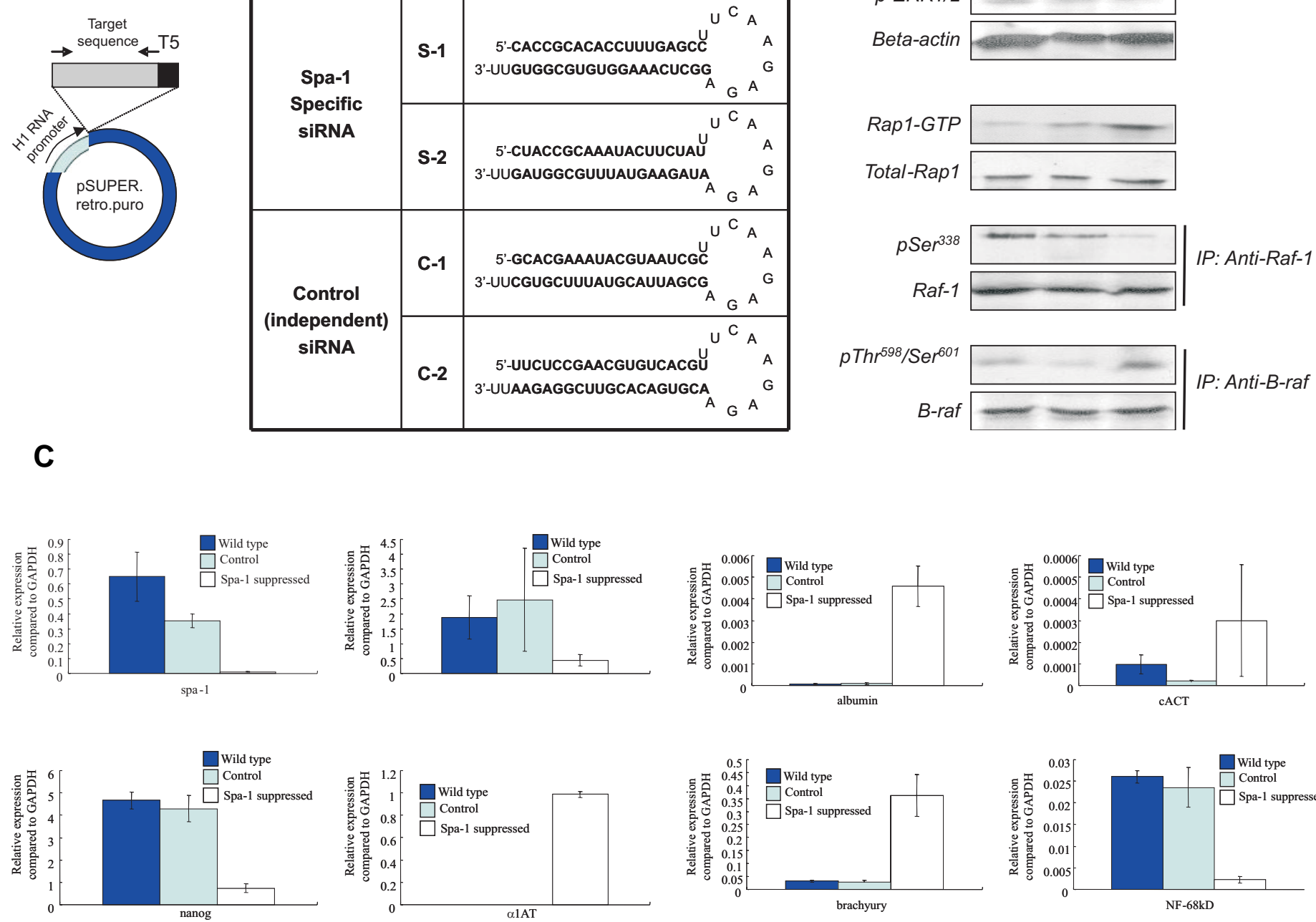

B


Fig. 7. Vector-based suppression of gene expression in hESCs. (A) Schematic of the pSUPER.retro.puro vector. The H1-RNA promoter cloned in front of the gene-specific targeting sequence (19-nucleotide, $19 \mathrm{nt}$, sequences from the target transcripts separated by a short spacer from the reverse complement of the same sequence) and 5 thymidines (T5) as a termination signal. The predicted secondary structures of pSUPER.retro.puro-spa-1 or pSUPER.retro.puro-control transcript and the synthetic siRNA used to target spa-1 are depicted. (B) Western blot analysis for activation level for ERK1/2, Rap1, Raf-1 and B-raf in wild or control or spa-1 suppressed AMC-hES1 cells. Stable suppression of gene expression. hESCs were cultured in Matrigel-coated plates and transfected with pSUPER.retro.puro-spa-1 (pSUPER-spa-1; used S1 target sequence) or pSUPER.retro.puro-control (used C1 oligo target sequence) vector. U, undifferentiated AMC-hES1 cells; Control, pSUPER.retro.puro-control transfected AMC-hES1 line; spa-1 $-l$, stably small interference (si)RNA expression vectors against the spa-1-transfected AMC-hES1 line. (C) After transfection, cells were harvested and spa-1 expression analyzed using quantitative real-time PCR to analyze their differentiation profiles. Values on the ordinate represent relative expression compared to GAPDH. 


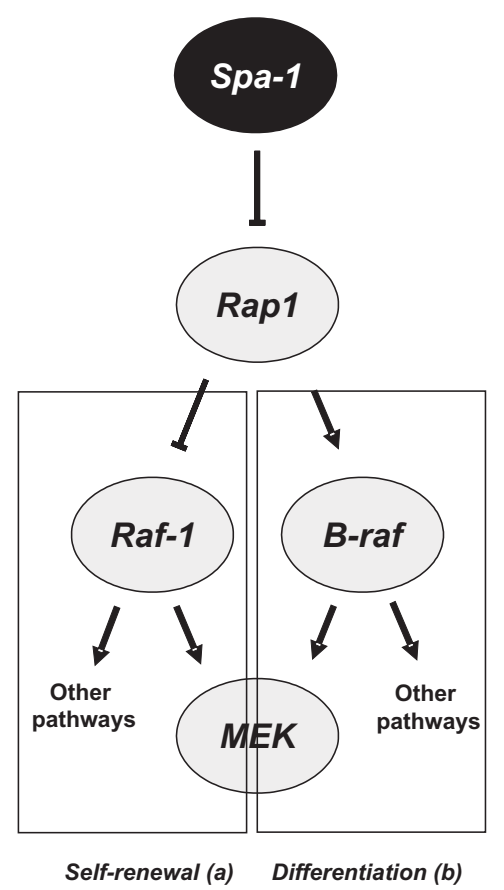

Fig. 8. A model of signaling among Spa-1, Rap1 and Rafs (Raf-1 and B-raf) for self-renewal and differentiation of hESCs. Depending upon the relative expression of spa-1 and rap1, raf-1 and B-raf was either phosphorylated (activation) or dephosphorylated (inactivation); these modulations could be one of the determinants of hESC self-renewal and differentiation.

renewal or differentiating mode. In the undifferentiated state, Raf1 is activated by inhibition of Rap1, which is regulated by spa-1, whereas B-raf- 1 is activated by the activation of Rap1.

The cellular mechanisms involved in the control of hESCs seem more complicated than those of mESCs, and the molecular mechanisms underlying the activity of key molecules (e.g., FGF2, LIF, Wnt, Oct-3/4, and Nanog) in the maintenance and differentiation of hESCs have yet to be clearly established. The results presented here, however, provide us with fundamental information regarding the cellular dynamics involved in the maintenance and differentiation of hESCs.

\section{Materials and Methods}

\section{Human embryo culture and isolation of the inner cell mass (ICM)}

hESC lines were established from six cryopreserved embryos that were donated for study with the approval of the institutional review board and after obtaining the informed consent of patients undergoing in vitro fertilization treatment. Embryos were cultured to blastocyst stage in G1.3/ G2.3 medium (Vitrolife, Sweden) in accordance with the manufacturer's instructions.

In vitro cultured blastocysts were removed from the zona pellucida with $0.5 \%$ pronase $\mathrm{E}$ (Sigma-Aldrich) in Dulbecco's modified Eagle's medium (DMEM)/F12 (Invitrogen, Carlsbad, CA) supplemented with 20\% knockout serum replacement (Invitrogen, Carlsbad, CA). ICMs were isolated from the blastocysts by immunosurgical removal of the trophectoderm using rabbit antihuman whole serum (Sigma-Aldrich) and guineapig complement (Sigma-Aldrich), and transferred on to a mitomycin C (Sigma-Aldrich)-treated mouse embryonic fibroblast (MEF) feeder layer (Solter et al., 1975). ICM outgrowths were passaged to plates with fresh medium and new primary MEF by mechanical dissection.

\section{Culture of hESCs and embryoid body formation}

$\mathrm{hESC}$ s were maintained on MEF feeder layers in DMEM/F12 (Invitrogen, Carlsbad, CA) supplemented with $20 \%$ knockout serum replacement (Invitrogen, Carlsbad, CA), $0.1 \mathrm{mM} \beta$-mercaptoethanol (Invitrogen, Carlsbad, CA), $0.1 \mathrm{mM}$ nonessential amino acids (Invitrogen, Carlsbad, CA), $100 \mathrm{U} / \mathrm{ml}$ penicillin G (Sigma Aldrich), $100 \mu \mathrm{g} / \mathrm{ml}$ streptomycin (Sigma Aldrich), and $4 \mathrm{ng} / \mathrm{ml}$ human recombinant bFGF (Invitrogen, Carlsbad, CA) at $37^{\circ} \mathrm{C}$ and in an atmosphere of $5 \% \mathrm{CO}_{2}$. MEFs were cultured primarily from 13.5-day postcoitum fetuses of CF-1 mice, as reported previously (Thomson et al., 1998), and hESC colonies were subcultured on new feeders every 5-7 days. Feeder-free culture of hESCs was performed as follows. Plates were incubated with growthfactor-reduced Matrigel (Becton Dickinson, Franklin Lakes, NJ) diluted to 1:30 in cold DMEM/F12 at $4^{\circ} \mathrm{C}$ for at least overnight, and conditioned medium (CM) prepared from MEF was used for maintenance of the hESCs under feeder-free conditions.

Mechanically dissociating hESCs induced embryoid body (EB) formation, and harvested hESCs were grown in suspension culture with the same hESC culture medium except that it lacked bFGF. At days 7,14 , and 21 after the beginning of culture, EB was prepared for RNA and protein isolation.

\section{Characterization of established hESCs}

Immunocytochemistry: Alkaline phosphatase (AP) activity and the expression of hESC-surface, stage-specific antigens were measured using an embryonic stem cell characterization kit (Chemicon, Temecula, CA) according to the manufacturer's instructions. Briefly, cultured hESCs were washed with PBS and fixed in a mixture of $90 \%$ methanol and $10 \%$ formalin. AP staining solutions (Chemicon, Temecula, CA) were added to fixed hESCs at room temperature for $15 \mathrm{~min}$. For analyses of hESCsurface, stage-specific antigen expressions, hESC colonies were washed in PBS, fixed with $4 \%$ formaldehyde for $15 \mathrm{~min}$ at room temperature, and then washed again three times in PBS. The following primary antibodies were used: SSEA-1, SSEA-3, SSEA-4, Tra-1-60, and Tra-1-81 (Chemicon, Temecula, CA). The primary antibodies were detected using $\mathrm{CY}^{\mathrm{T} M} \mathrm{M}_{5}$ conjugated goat anti-mouse or anti-rat IgG (Zymed, San Francisco, CA) as the secondary antibody.

Karyotyping: The hESCs were incubated in hESC culture medium with $0.1 \mu \mathrm{g} / \mathrm{ml}$ colcemid (KaryoMax colcemid solution; Invitrogen, Carlsbad, $\mathrm{CA}$ ) for $3 \mathrm{~h}$, dissociated (trypsinized), fixed in methanol:acetic acid (3:1, $\mathrm{v} / \mathrm{v}$ ), and mounted on glass slides. The chromosomes were visualized by Giemsa staining and the karyotype of hESCs determined by cytogeneticists

In Vivo Differentiation (Teratoma Assay) Analyses: For the teratoma assay, immunodeficient SCID mice (NOD.CB17-SCID/J, Charles River Laboratories, Wilmington, MA) were used. hESC colonies were mechanically detached from the surface and dissociated into small cell aggregates (clumps of 400-500 undifferentiated hESCs). Clumps were injected with a sterile 26-G needle into the testicular capsule of 5-week-old SCID mice. The resulting teratomas were analyzed histologically 12 weeks later.

\section{Oligo microarray}

Total RNA was isolated from undifferentiated hESCs and hESCderived differentiated cells (20-day EB) by using TriZol-reagent (GIBCOInvitrogen, Carlsbad, CA) according to the manufacturer's instructions, and purified by RNeasy mini kit (Qiagen, Valencia, CA). Fluorescentlylabeled probes for oligo microarray analysis were prepared by Amino allyl MessageAmp ${ }^{\mathrm{TM}}$ aRNA kit (Ambion Inc., Texas). Labeled probes (Cy5, hESCs; Cy3, 20-day EB) were hybridized to a Human 1A(V2) Oligo Microarray kit(Agilent Technologies, Palo Alto, CA) at $60^{\circ} \mathrm{C}$ for $16 \mathrm{~h}$. Slides were washed twice in $6 \times \mathrm{SSC} / 0.005 \%$ Triton X-102 at $60^{\circ} \mathrm{C}$ for 20 min and once in $0.1 \times$ SSC $/ 0.005 \%$ Triton X-102 at RT for 10 min and four times in D.W for 1 min and spin dried. DNA chips were scanned using 
ScanArray Lite (PerkinElmer Life Sciences, Billerica, MA). Scanned images were analyzed with GenePix 3.0 software (Axon Instruments, Union City, CA) to obtain gene expression ratios. Logged gene expression ratios were normalized by LOWESS regression (Yang et al., 2002). The statistical significance of the differential expression was assessed by computing a q-value for each gene. To determine the q-value we used a permutation procedure, and for each permutation two-sample t-statistics were computed for each gene. Genes were considered differentially expressed when logarithmic gene expression ratios in three independent hybridizations were more than 1 or less than -1 , i.e. a twofold difference in expression level, and when the q-value was $<0.1$.

Semiquantitative reverse-transcription polymerase chain reaction

Total RNA was extracted from undifferentiated or differentiated hESCs using an RNeasy Mini Kit (Qiagen, Valencia, CA) according to the manufacturer's instructions with RNase-Free DNase set (Qiagen, Valencia, CA). Briefly, lysis and homogenization of the hESCs and binding of RNA to the silica-gel membrane were performed according to the provided standard protocols, After washing with a reduced volume of Buffer RW1, the RNA was treated with DNase I while bound to the silica-gel membrane. The DNase was removed by a second wash with Buffer RW1. Washing with Buffer RPE and elution were then performed according to the provided standard protocol. RNA quality was ensured by gel visualization and spectrophotometric analysis $\left(\mathrm{OD}_{260 / 280}\right)$. First-strand cDNA was synthesized using avian myeloblastosis virus reverse transcriptase (Takara, Shiga, Japan) and random hexamers from $1 \mu \mathrm{g}$ of each total RNA. cDNA samples were subjected to PCR amplification with specific primers (Table 2) under appropriate conditions. The human glyceraldehyde-3-phosphate dehydrogenase gene was used as an internal control. All PCR products were electrophoresed in $1.2 \%$ agarose gels and stained with ethidium bromide (Sigma Aldrich). FirstChoice Human Total RNA

\section{TABLE 2}

\section{PRIMER SEQUENCES FOR REVERSE TRANSCRIPTASE- POLYMERASE CHAIN REACTION}

\begin{tabular}{|c|c|c|}
\hline Gene & Forward $(F)$ and reverse $(R)$ primer sequences & Product size (bp) \\
\hline spa-1 & $\begin{array}{l}F: 5^{\prime} \text {-caccgcacacctttgagcc-3' } \\
R: 5^{\prime} \text {-gtggctgcactctcagactc-3' }\end{array}$ & 461 \\
\hline \multicolumn{3}{|c|}{ Undifferentiated cell markers } \\
\hline Oct-3/4 & $\begin{array}{l}F: 5^{\prime}-\text { cttgctgcagaagtgggtggaggaa-3' } \\
\text { R: 5'-ctgcagtgtgggtttcgggca-3' }\end{array}$ & 169 \\
\hline Nanog & $\begin{array}{l}F: 5^{\prime} \text {-tgcctcacacggagactgtc-3' } \\
R: 5^{\prime} \text {-tgctattcttcggccagttg-3' }\end{array}$ & 354 \\
\hline Sox2 & $\begin{array}{l}\text { F: 5'-acaccaatcccatccacact-3' } \\
\text { R: 5'-gcaaacttcctgcaaagctc-3' }\end{array}$ & 224 \\
\hline \multicolumn{3}{|l|}{ Endoderm } \\
\hline$\alpha 1 A T$ & $\begin{array}{l}\text { F: 5'-actgtcaacttcggggacac-3' } \\
\text { R: 5'-ccccattgctgaagacctta-3' }\end{array}$ & 517 \\
\hline Albumin & $\begin{array}{l}F: \text { 5'-cttcctgggcatgttttgt-3' } \\
\text { R: 5'-ggttcaggaccacggataga-3' }\end{array}$ & 401 \\
\hline \multicolumn{3}{|l|}{ Mesoderm } \\
\hline$C A C T$ & $\begin{array}{l}\text { F: 5'-tatttgctcccttgcttgga-3' } \\
\text { R: 5'-cctaccccaaaaacaaacga-3' }\end{array}$ & 415 \\
\hline Brachyury & $\begin{array}{l}F: 5^{\prime} \text {-acgccatgtactccttcctg-3' } \\
\text { R: 5'-tgagcttgttggtgagcttg-3' }\end{array}$ & 204 \\
\hline \multicolumn{3}{|l|}{ Ectoderm } \\
\hline$N F-68 k D$ & $\begin{array}{l}\text { F: 5'-acgctgaggaatggttcaag-3' } \\
\text { R: 5'-tagacgcctcaatggtttcc-3' }\end{array}$ & 561 \\
\hline \multicolumn{3}{|c|}{ Housekeeping gene } \\
\hline GAPDH & $\begin{array}{l}F: 5^{\prime} \text {-gctgtggg gaaggtcatcc-3' } \\
\text { R: 5'-cttgctggggctggtggtc-3' }\end{array}$ & 391 \\
\hline
\end{tabular}

* oct-3/4, octamer-binding transcription factor $3 / 4$; sox2, SRY (sex determining region $\mathrm{Y}$ )-box 2 ; $\alpha 1 A T$, alpha-1 antitrypsin; $C A C T$, carnitine-acylcarnitine translocase; NF-68kD, 68-kD neurofilament subunit; $\ddot{A} G A P D H$, Glyceraldehyde-3-phosphate dehydrogenase; $b p$, base pairs.
Survey Panel (Ambion, Austin, TX) was used for total RNA of human adult tissues.

\section{Western blotting}

Undifferentiated, differentiated, and transient spa-1 -/- hESCs were lysed in Triton X-100 lysis buffer (1\% Triton X-100, 1 mM EDTA, $150 \mathrm{mM}$ $\mathrm{NaCl}, 50 \mathrm{mM} \mathrm{NaF}$, and a protease inhibitor mixture; Calbiochem, Darmstadt, Germany), and insoluble materials were precipitated by centrifugation at $16,000 \times \mathrm{g}$ for $10 \mathrm{~min}$ at $4^{\circ} \mathrm{C}$. The supernatant was transferred to a new tube and protein concentrations were determined by using a protein assay dye reagent (Bio-Rad, Hercules, CA) according to the manufacturer's recommendations. Twelve micrograms of each hESC lysate was resolved by $12 \%$ sodium dodecyl sulfate-polyacrylamide gel electrophoresis (SDS-PAGE), transferred to a nitrocellulose membrane, and then immunoblotted with anti-Spa-1 (BD Transduction Laboratories, San Jose, CA), anti-Rap1 (Santa Cruz Biotechnology, Santa Cruz, CA), anti-Raf-1 (Santa Cruz Biotechnology, Santa Cruz, CA), anti-B-raf (Santa Cruz Biotechnology, Santa Cruz, CA), anti-Oct-3/4 (Santa Cruz Biotechnology, Santa Cruz, CA), anti-phospho-p44/42 MAP kinase (ERK1/2; Cell Signaling Technologies, MA) or anti-Beta-actin (Santa Cruz Biotechnology, Santa Cruz, CA) antibody. Binding of primary antibodies was detected by incubating blots with horseradish-peroxidase-conjugated goat antirabbit or antimouse antibody, and blots were developed using enhanced chemiluminescence (Western blotting detection reagents; Amersham Biosciences, Piscataway, NJ).

\section{Rap-1 activation assay using RaIGDS-RBD}

Lysates derived from undifferentiated or differentiated (day-21 EBs) hESCs were clarified by centrifugation at $16,000 \times \mathrm{g}$ for $10 \mathrm{~min}$ at $4^{\circ} \mathrm{C}$. Thirteen micrograms of RalGDS-RBD, coupled to agarose beads (Upstate Biotechnology, Lake Placid, NY), were added to lysates and incubated at $4^{\circ} \mathrm{C}$ for $45 \mathrm{~min}$ with slight agitation. After brief centrifugation, the resulting pellet was washed three times with $1 \mathrm{X}$ Tris lysis buffer $(50$ $\mathrm{mM}$ Tris- $\mathrm{HCl}, \mathrm{pH} 7.4,0.5 \mathrm{M} \mathrm{NaCl}, 1 \% \mathrm{NP}-40,2.5 \mathrm{mM} \mathrm{MgCl}_{2}$, and $5 \%$ glycerol). After the final wash, protein sample buffer was added to the samples, and proteins were resolved by $12 \%$ SDS-PAGE and transferred to nitrocellulose membranes. The blot was probed with rabbit anti-Rap1 antibody (Santa Cruz Biotechnology, Santa Cruz, CA) to determine the degree of Rap1 activation.

\section{Immunoprecipitation}

Total cell lysates were obtained with Triton X-100 lysis buffer from undifferentiated and differentiated (day-21 EBs) hESCs. Raf-1 and B-raf protein was immunoprecipitated with rabbit-anti-raf-1 or rabbit anti-B-raf antibody (Santa Cruz Biotechnology, Santa Cruz, CA), respectively, and protein A-Sepharose beads. Immunoprecipitates were washed three times with $1 \mathrm{ml}$ of high-salt buffer and once with $1 \mathrm{ml}$ of $20 \mathrm{mM}$ Tris- $\mathrm{Cl}(\mathrm{pH}$ 8.0 ), resuspended in $5 X$ protein sample buffer, resolved by $12 \%$ SDSPAGE, and then transferred to nitrocellulose membranes. Phosphorylation of $\mathrm{Ser}^{338}$ (for Raf-1) or Thr ${ }^{598} / \mathrm{Ser}^{601}$ (for B-raf) was detected by immunoblotting using mouse anti-phospho-Ser ${ }^{338}$ Raf-1 antibody (Upstate Biotechnology, Lake Placid, NY) or goat anti-phospho-Thr ${ }^{598} / \mathrm{Ser}^{601}$ B-raf antibody (Santa Cruz Biotechnology, Santa Cruz, CA), respectively. Blots were reprobed with rabbit anti-Raf-1 (Santa Cruz Biotechnology, Santa Cruz, CA) or anti-B-raf (Santa Cruz Biotechnology, Santa Cruz, $\mathrm{CA}$ ) antibody to determine the amount of immunoprecipitated Raf-1 or Braf protein, respectively.

\section{Small interference RNA (siRNA)}

pSUPER.retro.puro vector (mammalian expression vector; OligoEngine, Seattle, WA) was used for the expression of siRNA in hESCs. The spa-1-specific insert specified a 19-nucleotide sequence corresponding to nucleotides 107-125 (5'-caccgcacacctttgagcc-3') or 651-669 (5'-ctaccgcaaatacttctat-3') downstream of the translation start codon of spa-1 (NCBI GenBank, AF029789), which are separated by a 9- 
nucleotide noncomplementary spacer (5'-ttcaagaga-3') from the reverse complement of the same 19-nucleotide sequence (pSUPER-spa-1). Two control vectors were constructed using a 19-nucleotide sequence (5'gcacgaaatacgtaatcgc-3' and 5'-ttctccgaacgtgtcacgt-3') with no homology to any human mRNA sequence in GenBank. siRNA expression vectors were constructed as follows: 19 nucleotide sequences were inserted into the pSUPER.retro.puro backbone after digestion with BgIII and Hind III (New England Biolabs, Beverly, MA) and transformed into competent JM109 cells (Invitrogen, Carlsbad, CA) according to the manufacturer's instructions. The confirmation of constructs was performed by digestion with several restriction enzymes, electrophoresis, and nucleotide sequencing.

\section{Transfection into hESCs}

Transfection of hESCs was carried out in 12-well plates (Nunc, Rochester, NY) under feeder-free culture conditions, as per the manufacturer's protocol. Briefly, $2 \mu \mathrm{g}$ of vector constructs was diluted in $50 \mu \mathrm{l}$ of $0.15 \mathrm{M} \mathrm{NaCl}$, and $6.6 \mu \mathrm{l}$ Exgen 500 solution (Fermentas, Ontario, Canada) was added to $43.4 \mu \mathrm{l}$ of $0.15 \mathrm{M} \mathrm{NaCl}$. Diluted DNA and Exgen 500 solution were mixed well and incubated at room temperature for 10 min. Each feeder-free cultured hESC was transfected with DNA/Exgen 500 solution and incubated at $37^{\circ} \mathrm{C}$ in an atmosphere of $5 \% \mathrm{CO}_{2}$. For stable expression, the cells were passed 3 days after transfection onto Matrigel-coated, feeder-free culture plates with $\mathrm{CM}$, and after 3 days, puromycin $(1 \mu \mathrm{g} / \mathrm{ml}$ final concentration) was added for 7 days. Puromycinresistant hESCs were selected, dissociated, and plated onto MEF-coated plates for further studies.

\section{Quantitative real-time analysis}

To analyze differentiation profile of spa-1-suppressed hESCs, the quantitative real-time PCR was performed in an ABI Prism 7000 Sequence Detector (Applied Biosystems, USA) using SYBR Green PCR Master Mix (Applied Biosystems) as the detector according to the manufacturer's instruction. A PCR reaction mixture of $20 \mu$ l containing 10 $\mu \mathrm{l}$ of SYBR Green PCR Master Mix, $3 \mu \mathrm{l}$ of each CDNA and a pair of primers (Table 2). Specific PCR products were detected with the fluorescent double stranded DNA-binding dye, SYBR Green (Morrison et al., 1998). PCR amplification was performed in triplicate and replicated in three independent experiments. Gel electrophoresis and melting curve analyses were performed to confirm correct PCR product sizes and absence of nonspecific bands. The expression levels of each gene were normalized against gapdh using the comparative $C_{T}$ method according to the manufacturer's protocols (Applied Biosystems, Sequence Detection system User Bulletin \#2; Livak et al., 2001).

\section{Acknowledgements}

This work was supported by a research grant from the Asan Institute for Life Sciences (Grant number 2005-116).

\section{References}

ALAVI, A., HOOD, J.D., FRAUSTO, R. STUPACK, D.G. and CHERESH, D.A. (2003). Role of Raf in vascular protection from distinct apoptotic stimuli. Science 301: 94-96.

AMIT, M., SHARIKI, C., MARGULETS, V. and ITSKOVITZ-ELDOR, J. (2004). Feeder layer- and serum-free culture of human embryonic stem cells. Biol. Reprod. 70: 837-845.

ARMSTRONG, L., HUGHES, O., YUNG, S., HYSLOP, L., STEWART, R., WAPPLER, I., PETERS, H., WALTER, T., STOJKOVIC, P., EVANS, J., STOJKOVIC, M. and LAKO, M. (2006). The role of PI3K/AKT, MAPK/ERK and NFkappabeta signalling in the maintenance of human embryonic stem cell pluripotency and viability highlighted by transcriptional profiling and functional analysis. Hum. Mol. Genet. 15: 1894-1913.

ANDREWS, P.W. (1984). Retinoic acid induces neuronal differentiation of a cloned human embryonal carcinoma cell line in vitro. Dev. Biol. 103: 285-293.
ANDREWS,.PW., BANTING, G., DAMJANOV, I., ARNAUD, D. and AVNER, P (1984) Three monoclonal antibodies defining distinct differentiation antigens associated with different high molecular weight polypeptides on the surface of human embryonal carcinoma cells. Hybridoma 3: 347-361.

BABAIE, Y., HERWIG, R., GREBER, B., BRINK, T.C., WRUCK, W., GROTH, D., LEHRACH, H., BURDON, T., ADJAYE, J. (2007). Analysis of Oct4-dependent transcriptional networks regulating self-renewal and pluripotency in human embryonic stem cells. Stem Cel/s 25: 500-510.

BOS, J.L., DE, ROOIJ. J. and REEDQUIST, K.A. (2001). Rap1 signalling: adhering to new models. Nat. Rev. Mol. Cell. Biol. 2: 369-377.

BOYER, L.A., LEE, T.I., COLE, M.F., JOHNSTONE, S.E., LEVINE, S.S., ZUCKER, J.P., GUENTHER, M.G., KUMAR, R.M., MURRAY, H.L., JENNER, R.G., GIFFORD, D.K., MELTON, D.A., JAENISCH, R., YOUNG, R.A. (2005) Core transcriptional regulatory circuitry in human embryonic stem cells. Cel/ 122: 947-956.

BURDON, T., CHAMBERS, I., STRACEY, C., NIWA, H. and SMITH, A. (1999). Signaling mechanisms regulating self-renewal and differentiation of pluripotent embryonic stem cells. Cells Tissues Organs. 165: 131-143.

CAREY, K.D., WATSON, R.T., PESSIN, J.E. and STORK, P.J. (2003). The requirement of specific membrane domains for Raf-1 phosphorylation and activation. J. Biol. Chem. 278: 3185-3196.

CARON, E. (2003). Cellular functions of the Rap1 GTP-binding protein: a pattern emerges. J. Cell. Sci. 116: 435-440.

CHILOECHES, A., MASON, C.S. and MARAIS, R. (2001). S338 phosphorylation of Raf-1 is independent of phosphatidylinositol 3-kinase and Pak3. Mol. Cell. Biol. 21: 2423-2434.

COOK, S.J., RUBINFELD, B., ALBERT, I. and MCCORMICK, F. (1993). RapV12 antagonizes Ras-dependent activation of ERK1 and ERK2 by LPA and EGF in Rat-1 fibroblasts. EMBO J. 12: 3475-3485.

DUPUY, A.J., MORGAN, K., VON, LINTIG, F.C., SHEN, H., ACAR, H., HASZ, D.E., JENKINS, N.A., COPELAND, N.G., BOSS, G.R. and LARGAESPADA, D.A. (2001). Activation of the Rap1 guanine nucleotide exchange gene, CalDAGGEF I, in BXH-2 murine myeloid leukemia. J. Biol. Chem. 276: 11804-11811.

DVORAK, P., DVORAKOVA, D., KOSKOVA, S., VODINSKA, M., NAJVIRTOVA, M., KREKAC, D. and HAMPL, A. (2005). Expression and potential role of fibroblast growth factor 2 and its receptors in human embryonic stem cells. Stem Cells 23: 1200-1211.

FENDERSON, B.A., ANDREWS, P.W., NUDELMAN, E., CLAUSEN, H. and HAKOMORI, S. (1987). Glycolipid core structure switching from globo- to lactoand ganglio-series during retinoic acid-induced differentiation of TERA-2derived human embryonal carcinoma cells. Dev. Biol. 122: 21-34.

GAO, Q., SRINIVASAN, S., BOYER, S.N., WAZER, D.E. and BAND, V. (1999). The E6 oncoproteins of high-risk papillomaviruses bind to a novel putative GAP protein, E6TP1, and target it for degradation. Mol. Cell. Biol. 19: 733-744.

GAO, Q., SINGH, L., KUMAR, A., SRINIVASAN, S., WAZER, D.E. and BAND, V. (2001) Human papillomavirus type 16 E6-induced degradation of E6TP1 correlates with its ability to immortalize human mammary epithelial cells. $J$. Virol. 75: 4459-4466.

GREBER, B., LEHRACH, H., ADJAYE, J. (2007). Fibroblast growth factor 2 modulates transforming growth factor beta signaling in mouse embryonic fibroblasts and human ESCs (hESCs) to support hESC self-renewal. Stem Cells 25: $455-464$.

HATTORI, M., TSUKAMOTO, N., NUR-E-KAMAL, M.S., RUBINFELD, B., IWAI, K., KUBOTA, H., MARUTA, H. and MINATO, N. (1995). Molecular cloning of a novel mitogen-inducible nuclear protein with a Ran GTPase-activating domain that affects cell cycle progression. Mol. Cell. Biol. 15: 552-560.

HUMPHREY, R.K., BEATTIE, G.M., LOPEZ, A.D., BUCAY, N., KING, C.C., FIRPO, M.T., ROSE-JOHN, S. and HAYEK, A. (2004) Maintenance of pluripotency in human embryonic stem cells is STAT3 independent. Stem Cel/s 22: 522-530.

ISHIDA, D., KOMETANI, K., YANG, H., KAKUGAWA, K., MASUDA, K., IWAI, K., SUZUKI, M., ITOHARA, S., NAKAHATA, T., HIAI, H., KAWAMOTO, H., HATTORI, M. and MINATO, N. (2003). Myeloproliferative stem cell disorders by deregulated Rap1 activation in SPA-1-deficient mice. Cancer Ce//4: 55-65.

JAMES, D., LEVINE, A.J., BESSER, D. and HEMMATI-BRIVANLOU, A. (2005). TGFbeta/activin/nodal signaling is necessary for the maintenance of pluripotency in human embryonic stem cells. Development 132: 1273-1282. 
KOMETANI, K., ISHIDA, D., HATTORI, M. and MINATO, N. (2004). Rap1 and SPA1 in hematologic malignancy. Trends. Mol. Med. 10: 401-408.

KURACHI, H., WADA, Y., TSUKAMOTO, N., MAEDA, M., KUBOTA, H., HATTORI, M., IWAI, K. and MINATO, N. (1997). Human SPA-1 gene product selectively expressed in lymphoid tissues is a specific GTPase-activating protein for Rap1 and Rap2. Segregate expression profiles from a rap1GAP gene product. J. Biol. Chem. 272: 28081-28088.

LIVAK, K. J. and SCHMITTGEN, T.D. (2001). Analysis of relative gene expression data using real-time quantitative PCR and the $2(-[/$ Delta] $] /$ Delta] $C(T))$ method. Method 25: 402-408

MATSUDA, T., NAKAMURA, T., NAKAO, K., ARAI, T., KATSUKI, M., HEIKE, T. and YOKOTA, T. (1999). STAT3 activation is sufficient to maintain an undifferentiated state of mouse embryonic stem cells. EMBO J. 18: 4261-4269.

MERCER, K.E. and PRITCHARD, C.A. (2003). Raf proteins and cancer: B-Raf is identified as a mutational target. Biochim. Biophys. Acta. 1653: 25-40.

MITALIPOVA, M., CALHOUN, J., SHIN, S., WININGER, D., SCHULZ, T., NOGGLE, S., VENABLE, A., LYONS, I., ROBINS, A. and STICE, S. (2003). Human embryonic stem cell lines derived from discarded embryos. Stem Cells21:521526.

MITSUI, K., TOKUZAWA, Y., ITOH, H., SEGAWA, K., MURAKAMI, M., TAKAHASHI, K., MARUYAMA, M., MAEDA, M. and YAMANAKA, S. (2003). The homeoprotein Nanog is required for maintenance of pluripotency in mouse epiblast and ES cells. Cel/113: 631-642.

MOCHIZUKI, N., OHBA, Y., KIYOKAWA, E., KURATA, T., MURAKAMI, T., OZAKI, T., KITABATAKE, A., NAGASHIMA, K., MATSUDA, M. (1999). Activation of the ERK/MAPK pathway by an isoform of rap1GAP associated with $G$ alpha. Nature 400:891-894

MORRISON, T.B., WEIS, J.J. and WITTWER, C.T. (1998). Quantification of lowcopy transcripts by continuous SYBR Green I monitoring during amplification. Biotechniques 24: 954-958.

NIWA, H., BURDON, T., CHAMBERS, I. and SMITH, A. (1998). Self-renewal of pluripotent embryonic stem cells is mediated via activation of STAT3. Genes. Dev. 12: 2048-2060.

NIWA, H. (2001). Molecular mechanism to maintain stem cell renewal of ES cells. Cell Struct. Funct. 26: 137-148.

O'NEILL, E. and KOLCH, W. (2004). Conferring specificity on the ubiquitous Raf/ MEK signalling pathway. Br. J. Cancer 90: 283-288.

PAK, D.T., YANG, S., RUDOLPH-CORREIA, S., KIM, E. and SHENG, M. (2001). Regulation of dendritic spine morphology by SPAR, a PSD-95-associated RapGAP. Neuron 31: 289-303.

PAPAIOANNOU, V.E., WATERS, B.K. and ROSSANT, J. (1984). Interactions between diploid embryonal carcinoma cells and early embryonic cells. Cell Differ. 15: 175-179.

PARK, J.H., KIM, S.J., OH, E.J., MOON, S.Y., ROH, S.I., KIM, C.G. and YOON, H.S. (2003). Establishment and maintenance of human embryonic stem cells on STO, a permanently growing cell line. Biol. Reprod. 69: 2007-2014.

PEASE, S., BRAGHETTA, P., GEARING, D., GRAIL, D. and WILLIAMS, R.L. (1990). Isolation of embryonic stem (ES) cells in media supplemented with recombinant leukemia inhibitory factor (LIF). Dev. Biol. 141: 344-352.

PROWSE, A.B., MCQUADE, L.R., BRYANT, K.J., VAN, DYK, D.D., TUCH, B.E. and GRAY, P.P. (2005). A proteome analysis of conditioned media from human neonatal fibroblasts used in the maintenance of human embryonic stem cells. Proteomics 5: 978-989.

RAO, R.R., CALHOUN, J.D., QIN, X., REKA,Y.A.R., CLARK, J.K. and STICE, S.L. (2004). Comparative transcriptional profiling of two human embryonic stem cell lines. Biotechnol. Bioeng. 88: 273-286.

REUBINOFF, B.E., PERA, M.F., FONG, C.Y., TROUNSON, A. and BONGSO, A. (2000). Embryonic stem cell lines from human blastocysts: somatic differentiation in vitro. Nat. Biotechnol. 18: 399-404.

ROSSANT, J. and PAPAIOANNOU, V.E. (1984). The relationship between embryonic, embryonal carcinoma and embryo-derived stem cells. Cel/ Differ. 15: 155161.
ROUSSEAU-MERCK, M.F., PIZON, V., TAVITIAN, A. and BERGER, R. (1990). Chromosome mapping of the human RAS-related RAP1A, RAP1B, and RAP2 genes to chromosomes $1 \mathrm{p} 12, \mathrm{p} 13,12 \mathrm{q} 14$, and 13q34, respectively. Cytogenet. Cell Genet. 53: 2-4.

ROY, S., MCPHERSON, R.A., APOLLONI, A., YAN, J., LANE, A., CLYDE-SMITH, J. and HANCOCK, J.F. (1998). 14-3-3 facilitates Ras-dependent Raf-1 activation in vitro and in vivo. Mol. Cell. Biol. 18: 3947-3955.

ROY, B.C., KOHU, K., MATSUURA, K., YANAI, H. and AKIYAMA, T. (2002). SPAL, a Rap-specific GTPase activating protein, is present in the NMDA receptorPSD-95 complex in the hippocampus. Genes Cells 7: 607-617.

SATO, N., MEIJER, L., SKALTSOUNIS, L., GREENGARD, P. and BRIVANLOU, A.H. (2004). Maintenance of pluripotency in human and mouse embryonic stem cells through activation of Wnt signaling by a pharmacological GSK-3-specific inhibitor. Nat. Med. 10: 55-63.

SCHMITT, J.M. and STORK, P.J. (2001). Cyclic AMP-mediated inhibition of cell growth requires the small G protein Rap1. Mol. Cell. Biol. 21: 3671-3683.

SCHURINGA, J.J., VAN, DER, SCHAAF, S., VELLENGA, E., EGGEN, B.J. and KRUIJER, W. (2002). LIF-induced STAT3 signaling in murine versus human embryonal carcinoma (EC) cells. Exp. Cell. Res. 274: 119-129.

SHAMBLOTT, M.J., AXELMAN, J., WANG, S., BUGG, E.M., LITTLEFIELD, J.W., DONOVAN, P.J., BLUMENTHAL, P.D., HUGGINS, G.R. and GEARHART, J.D. (1998). Derivation of pluripotent stem cells from cultured human primordial germ cells. Proc. Natl. Acad. Sci. USA 95: 13726-13731.

SOLTER, D. and KNOWLES, B.B. (1975). Immunosurgery of mouse blastocyst. Proc. Natl. Acad. Sci. USA 72: 5099-5102.

STORK, P.J. (2003). Does Rap1 deserves a bad Rap? Trends. Biochem. Sci. 28 : 267-275.

THOMSON, J.A., ITSKOVITZ-ELDOR, J., SHAPIRO, S.S., WAKNITZ, M.A., SWIERGIEL, J.J., MARSHALL, V.S. and JONES, J.M. (1998). Embryonic stem cell lines derived from human blastocysts. Science 282: 1145-1147.

THOMSON, J.A. and ODORICO, J.S. (2000). Human embryonic stem cell and embryonic germ cell lines. Trends. Biotechnol. 18: 53-57.

VOSSLER, M.R., YAO, H., YORK, R.D., PAN, M.G., RIM, C.S. and STORK, P.J. (1997). cAMP activates MAP kinase and Elk-1 through a B-Raf- and Rap1dependent pathway. Cel/89: 73-82.

WADA, Y., KUBOTA, H., MAEDA, M., TANIWAKI, M., HATTORI, M., IMAMURA, S., IWAI, K. and MINATO, N. (1997). Mitogen-inducible SIPA1 is mapped to the conserved syntenic groups of chromosome 19 in mouse and chromosome 11 13.3 centromeric to BCL1 in human. Genomics 39: 66-73.

WALSH, J. and ANDREWS, P.W. (2003). Expression of Wnt and Notch pathway genes in a pluripotent human embryonal carcinoma cell line and embryonic stem cell. Apmis 111: 197-210.

WONG, K.F. (1999). 11q13 is a cytogenetically promiscuous site in hematologic malignancies. Cancer Genet. Cytogenet. 113: 93-95.

YAJNIK, V., PAULDING, C., SORDELLA, R., MCCLATCHEY, A.I., SAITO, M., WAHRER, D.C., REYNOLDS, P., BELL, D.W., LAKE, R., VAN, DEN, HEUVEL, S., SETTLEMAN, J. and HABER, D.A. (2003). DOCK4, a GTPase activator, is disrupted during tumorigenesis. Cel/112: 673-684.

YANG, Y.H., DUDOIT, S., LUU, P., LIN, D.M., PENG, V., NAGI, J. and SPEED, T.P. (2002). Normalization for cDNA microarray data: a robust composite method addressing single and multiple slide systematic variation. Nucl. Acid. Res. 30: e15

YING, Q.L., NICHOLS, J., CHAMBERS, I. and SMITH, A. (2003). BMP induction of Id proteins suppresses differentiation and sustains embryonic stem cell selfrenewal in collaboration with STAT3. Cel/115: 281-292.

YOSHIDA, K., CHAMBERS, I., NICHOLS, J., SMITH, A., SAITO, M., YASUKAWA, K., SHOYAB, M., TAGA, T. and KISHIMOTO, T. (1994). Maintenance of the pluripotential phenotype of embryonic stem cells through direct activation of gp130 signalling pathways. Mech. Dev. 45: 163-171.

ZHANG, B.H. and GUAN, K.L. (2000). Activation of B-Raf kinase requires phosphorylation of the conserved residues Thr598 and Ser601. EMBO. J. 19: 54295439. 


\section{Related, previously published Int. J. Dev. Biol. articles}

See our Special Issue Ear Development edited by Fernando Giraldez and Bernd Fritzsch at: http://www.ijdb.ehu.es/web/contents.php?vol=51\&issue=6-7

Interplay between FGF10 and Notch signalling is required for the self-renewal of pancreatic progenitors

Francisco Miralles, Luciane Lamotte, Dominique Couton and Rajiv L. Joshi

Int. J. Dev. Biol. (2006) 50: 17-26

Common culture conditions for maintenance and cardiomyocyte differentiation of the human embryonic stem cell lines, BG01 and HUES-7 Chris Denning, Cinzia Allegrucci, Helen Priddle, Maria D. Barbadillo-Muñoz, David Anderson, Tim Self, Nigel M. Smith, C. Tony Parkin and Lorraine E. Young

Int. J. Dev. Biol. (2006) 50: 27-37

A simple and efficient cryopreservation method for primate embryonic stem cells Tsuyoshi Fujioka, Kentaro Yasuchika, Yukio Nakamura, Norio Nakatsuji and Hirofumi Suemori Int. J. Dev. Biol. (2004) 48: 1149-1154

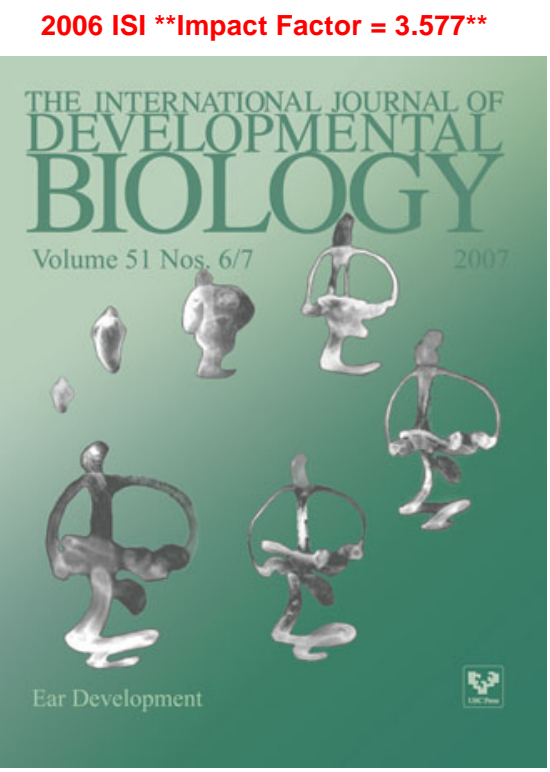

